\title{
THE FORMATION OFTHE LAND COURT SYSTEM IN THE GRAND DUCHY OF LITHUANIA (1564-1588)
}

\author{
Darius Vilimas
}

ABSTRACT This article investigates the formation of the system of land courts in the Grand Duchy of Lithuania in the period between 1564 and 1588. This process was an integral part of the social and structural modernisation of the GDL in the second half of the sixteenth century.

The powiat (district) land courts of the GDL were formally established between 1564 and 1566 in the aftermath of administrative and legal reforms. An analysis of the changes of the officials of land courts and their kinship relations has revealed the beginning of the formation of powiat land court officials as a specific group.

The purpose of the land court reform was to formalise the equality of the entire ruling gentry 'nation' before the law. However, the magnate families of the GDL managed to preserve both their possessed wealth and high posts.

Introduction Up to now the investigators of the sixteenth-century legal culture of the Grand Duchy of Lithuania have concentrated their attention on research into the process of law codification in the Lithuanian Statutes of 1529, 1566 and 1588. However, the development of legal culture in gentry society has not been studied. The works of Matvei Liubavskii, Ivan Lappo, Juliusz Bardach and others deal mainly with only one aspect of the problem - the efforts of the gentry to reform the existing court system, to establish an elected gentry court and to withdraw the privileges of the nobility. However, even the mechanism of the implementation of these objectives and the creation of the land court as a new institution have lacked proper attention.

The formation of land courts in the GDL was a long process, which started early in the sixteenth century when the Statute of 1529 envisaged a limited autonomy of the gentry courts. Since 1540 s in some administrative centres of the state there already functioned the courts called land courts in the Statute of 1529; subsequently they 
developed from the courts appointed by the administrator of the sovereign into the courts of 'selected' judges. Law court books were written regularly. Nevertheless, the old land court is not to be associated with the post-reform self-governing judicial body, since its officials were appointed by the ruler, and besides, noblemen were not subject to their jurisdiction, instead they could be tried only by the ruler. The very name of the court was not yet settled.

The actual history of the land court began with the privilege of Sigismund Augustus issued in Bielsk on 1 August 1564, which declared the formal legal equality of the gentry estate in the broad sense of the term and acknowledged the establishment of elected land courts in the powiats within the entire territory of the GDL. That was formalised legally by the Second Statute which came into effect at the beginning of 1566 .

The establishment of land courts was an integral part of the modernisation processes of GDL society in the latter half of the sixteenth century and could not be divorced from the general structural modernisation of the state. Historians maintain that the second half of the sixteenth century was characterised by a situation in which the middling and petty gentry began to develop as an independent numerous layer with its own interests and ways of safeguarding them. This opinion became prevalent after the appearance of substantive works by Liubavskii and Lappo in the early twentieth century. Liubavskii wrote a history of the sejm of the GDL, and Lappo a history of the powiat and dietine of Lithuania. According to these authors, the noblemen, who dominated in the life of the state, had to take into account the requirements of the gentry, since the war against Muscovy required rallying the forces of society, civil concord and financial resources.

Internal processes, taking place in the GDL were linked to one more problem - the relations with Poland, the 'executive' movement and its effect on the bearing of the Lithuanian gentry. Nearly all Polish historians accentuated the effect of the Polish legal culture on the corresponding reforms in the GDL. Some even maintained that after 1569 the law of the GDL was merely a part of Polish law (Oswald Balzer, Jan Adamus). Neither Lithuanian (Augustinas Janulaitis, Adolfas Šapoka) nor Soviet (Vladimir Picheta) historians denied such influence. In the latter half of the twentieth century a prominent Polish legal historian Bardach even formulated and substantiated a statement of voluntary reception applying it to institutional innovations of the social and political life of the GDL and to 
their takeover from Poland. According to this historian, that takeover was sweeping, natural and without any signs of outward pressure. However, even in the atmosphere of the idea of the takeover of the Polish order (Mečislovas Jučas, Grzegor Błaszczyk, Henryk Lulewicz), there appeared doubts both about the effectiveness of the takeover and about the omnipotence of the gentry with respect to the nobility after 1566 (Edvardas Gudavičius, ${ }^{1}$ Jūratè Kiaupiené ${ }^{2}$ ).

In the middle of the sixteenth century the internal situation became more complicated, and the nobility, seeing the equation of rights of different gentry groups as a lesser evil, made a resolve to detract it from the union ideas and to get support for carrying on the war. In the 1560 s the ruling elite of the GDL had two alternatives - to continue the war without Polish support and without any internal social backing from the lesser and middle gentry, not yet fully fledged but increasingly radicalising, and to ensure the gentry's support by decreasing its discontent and establishing formal equality of the whole gentry 'nation'.

The elite of the GDL perceived the inevitability of a closer union with Poland and understood the accompanying danger to the statehood of the GDL. The Lithuanian elite preferred the union with Poland to be one between equal partners. However, that could not be achieved without equating Polish and Lithuanian state structures and making Lithuania an equal partner of the union. Legal and administrative organs of the GDL were not yet properly structured. Judicial privileges of the GDL nobility and an uneven territorial division of the state were the chief obstacles in the path of an equitable union. The solution of these problems began in the Bielsk Sejm of 1564.

Given such a version of the development of events and their causes, the behaviour of the nobility prior to 1569 could be regarded as purposeful action on the eve of union in order to gain time and implement the structural modernisation of the GDL. The division of the state into palatinates and powiats, and the establishment of elected gentry powiat courts brought the structures of the two states closer together. In this connection it must be stressed that the GDL, which had its own legal system (the First Statute), took over from

${ }^{1}$ E. Gudavičius, 'Kas buvo XVI a. Lietuvos bajorija?', Lietuvos valstybe XIIXVIII a. (Vilnius, 1997), pp. 143-144.

2 J. Kiaupienè, ,,Mes, Lietuva”. Lietuvos Didžiosios Kunigaikštystès bajorija XVI a. (viešasis ir privatus gyvenimas) (Vilnius, 2003), pp.156-159. 
Poland not the Law of Poland, but only the organisation of the system of law courts. Therefore after the 1564-1566 reform of the courts and administration having improved its state structure, the GDL could participate in the negotiations about the conditions of the union with Poland as an equal partner. Further events will show that despite enormous pressure of the political elite of Poland on the ruler and despite some territorial loss the accepted union project was a compromise, preserving the sovereignty of the GDL.

The nobility perceived the danger of the gentry's movement for its rights and decided to guide it rather than to oppose it. Assuming such unconventional gentry 'emancipation' as a general modernisation of the GDL it is necessary to acknowledge that by requiring the establishment of an independent land court the gentry partially conducted the policy of state arrangement foreseen by the nobility. It was already Lappo who, referring to the indispensable reforms in the GDL and citing Mikalojus Radvila the Black's statement about 'a well-ordered republic', did not reject such a course of events. So far it is hard to state unequivocally to what extent the GDL gentry took the course of modernisation independently or was affected. The solution of this problem is linked to the degree of the gentry's selfconsciousness and mentality, which is not the subject of this research.

The course of the court reform has been investigated quite extensively and these studies must be continued only by adding the data of new sources or discussing the nature of the reform. Meanwhile the personalities of powiat land court officials have not been studied and have not been the subject of special research. It is important to examine this group of court officials in greater detail, since they formed an intermediate layer of the gentry, which in the late sixteenth century gave rise to the elite families of a new state, influential in the GDL in the seventeenth and eighteenth centuries.

In the formation of the GDL land courts there are several unsolved issues. Although all the conditions of the adoption of the Second Statute are known it is not clear when local land courts actually started functioning, whether their work corresponded to the regulations of the Second Statute, whether local land courts as new legal institutions were provided with premises necessary for their functioning, whether they worked in one or in some places in the powiats, and whether court sessions were conducted according to a certain fixed schedule. It is also unclear whether the first officials of the land courts really were representatives of the middle gentry and what were their mutual relationships and place in the hierarchy in 
terms of property qualification. It is also debatable whether the Bielsk Charter of 1 June 1564 legally equating the gentry estate really meant an end to domination by the nobility.

This study covers the period between 1564 and 1588. In these years land courts were set up and started functioning in all powiats on the territory of the GDL. The starting point of this period is rather arbitrary, because it is related to the year 1564, marking the promulgation of the Bielsk Charter establishing such courts. There is some evidence that in that year the reform of the courts of 'appointed' judges and vicegerents had already started in several regions of the GDL (Vilnius, Grodno, Slonim, Kaunas, Trakai, etc.), and that there had been a certain tradition of chancery work and land-court record keeping. Thus the year 1564 is to serve as a boundary marking off the investigation of the books of law courts which had been conducted according to the regulations of the First Lithuanian Statute.

Between 1564 and 1588 the procedure and type of the land court became established, and local courts either accepted new law norms or discarded them if they were too difficult to implement in practice. In this way both the Second Statute and the work of the powiat land courts were developed.

With regard to powiat land courts the final chronological boundary should be not the beginning of 1588 marking the adoption of the Third Statute but the end of the year, since it came into force at the start of 1589 .

It is difficult to define the territory in relation to the object under investigation, since the area of the GDL underwent changes between 1564 and 1588. According to the administrative reform of 15641566 the territory of the GDL was divided into palatinates and powiats. In the period between 1566 and March 1569 the GDL consisted of 13 palatinates comprising 30 powiats (five powiats in Vilnius palatinate, four in Trakai, three in Podlasie, three in Volhynia, three in Novogrudek, two in Minsk, two in Vitebsk, two in Kiev, two in Brest-Litowsk, one each in Podolia, in Mstislav, Polotsk and the Duchy of Žemaitija). In March - June 1569 the palatinates of Kiev, Volhynia, Podlasie and Podolia were detached, and the powiat of Mozyr (part of Kiev palatinate) was attached to the GDL palatinate of Minsk. Then the GDL consisted of nine palatinates with 22 powiats. Its composition remained without any major changes until the very end of the eighteenth century (without Smolensk palatinate which belonged to the GDL between 1611 and 1654).

After the Union of Lublin (1569) there remained 22 powiats of the former 30 and seven palatinates instead of the former 11established 
in the administrative reform of 1564-1566. The state actually consisted of 30 powiats only five years; therefore in this research attention will be focused on the situation after 1569 .

Sources The real establishment of the new powiat courts in the GDL (and after the Union of Lublin, in the Commonwealth) is attested by the materials of the sejms, self-government bodies (dietines, conventions), privileges of the rulers on issues related to powiat court work and other archival documents.

In the GDL the extant manuscript land-court books provide the researcher with the most abundant evidence. The sejm resolutions and the ruler's decrees on the boundaries of the powiats and the privileges of land court officers offer detailed information on state courts, administrative reforms in adopting the Second Statute and the specifics of the appointment of officials of the new land courts. Regrettably, the Lithuanian Metrica and powiat court books do not present a full sequence of the change of land court officials, and a complete panorama of court functioning is missing.

At the turn of the nineteenth century a part of the documents of the GDL sejm were published as appendixes in the works of Liubavskii, ${ }^{3}$ Lappo $^{4}$ and Nikolai Maksimeiko, ${ }^{5}$ and in the serial publications of the Russian Historical Library (RIB) and of the Vilnius Paleographical Commission (AVAK). ${ }^{6}$ The series Volumina Legum ${ }^{7}$ reflects the petitions of the GDL gentry on particular issues of the work of law courts and the striving for perfection of the laws in operation. Mitrofan Dovnar-Zapolskii compiled and issued the materials of some pre-Lublin-Union sejms of the GDL. ${ }^{8}$ Some sixteenth-century muster rolls of the GDL and several Books of Public Affairs of the 1550s and 1560s of the Lithuanian Metrica or fragments thereof were published in the RIB series. ${ }^{9}$ The AVAK published the oldest land court books (or their fragments) of Grodno and

${ }^{3}$ M. Liubavskii, Litovsko-russkii seim. Prilozheniia (Moscow, 1900), pp. 133-232.

${ }^{4}$ I. Lappo, Velikoe Kniazhestvo Litovskoe vo vtoroi polovine XVI stoletiia. Litovsko-russkii povet i ego seimik. Prilozheniia, (Yuriev, 1911), pp. 1-155.

${ }^{5}$ N. Maksimeiko, Seimy Litovskogo-russkogo gosudarstva do Liublinskoi unii 1569 g. Prilozheniia, (Kharkov, 1902), pp. 129-205.

${ }^{6}$ Akty izdavaemye Vilenskoiu arkheograficheskoiu komissieiu dlia razbora drevnikh aktov (AVAK), 1-39 (Vilnius, 1865-1914).

7 Volumina Legum, 2 (St Petersburg, 1859).

${ }^{8}$ Dokumenty Moskovskogo Arkhiva Ministerstva Iustitsii, 1 (Moscow, 1897).

${ }^{9}$ Russkaia Istoricheskaia Biblioteka, 27 (1903), 30 (1914), 33 (1915). 
Slonim; they were mostly pre-reform powiat court books. This series also comprised some late-sixteenth-century books of the castle- (vols. 32,36 ) and steward courts (vol. 30), supplementing the information on those regions whose land court books did not survive. A book of the decrees of the Supreme Tribunal of the GDL, compiled from various collections, contains much interesting information. ${ }^{10}$ The publication of the Lithuanian Metrica, renewed at the end of the twentieth century, has produced several Books of Inscriptions and of Public Affairs relating to land courts; and several similar books are currently in preparation. To date the historians have published and investigated to some extent only about a quarter of the whole accumulation of historical sources, and the rest of it consists of archival documents. This research deals with the so far untapped material - the books of the powiat land courts of the GDL. The powiat land courts books, kept in Lithuanian and Belarusian archives from the six powiats of the former GDL, make up a new large complex of archival sources and enable researchers to re-create the general course of the establishment of the land court. There are 44 such land court books in Lithuanian and Belarusian archives. Book 21 of the three Lithuanian GDL powiats covering the period between 1566 and 1588 comprises 5,122 inscriptions on 7,173 pages, ${ }^{11}$ while 23 books of the three Belarusian powiats of the GDL contain 2,888 inscriptions on 5,950 pages. $^{12}$ Excluding separate documents, a total of 8,020 inscriptions $(13,123$ pages) were used in this research.

The majority of the powiat land court books of the GDL are unpublished as yet. In cases when the court books have not been preserved the beginning of the functioning of the law courts in such powiats can be determined by extant privileges on delimiting the boundaries of those particular powiats or by the copies of various documents or copies of the lost court books in other archival collections. Altogether materials of seven archives were used in this study (three in Lithuania, three in Poland and one in Belarus). The majority of their materials have not been examined previously.

The heraldry of the families of the Commonwealth gentry, published in the latter half of the nineteenth and in the first half of

${ }^{10}$ Vyriausiojo Lietuvos Tribunolo sprendimai (1583-1655), comp. A. Baliulis and V. Raudeliūnas (Vilnius, 1988).

${ }^{11}$ As regards the Kaunas Land Court Book no. 5 (VUB RS, f. 7, book no. 28) account is taken only of the data relating to the year 1588 .

${ }^{12}$ A fragment of Book 3 of the 1597 court session from Grodno is not included. 
the twentieth centuries was particularly useful in the study of the biographies of land court officials, especially the works of Adam Boniecki, ${ }^{13}$ Seweryn Uruski, ${ }^{14}$ Kaspar Niesiecki ${ }^{15}$ and others. ${ }^{16}$ Although the data of these works are incomplete and sketchy, they nevertheless supplement the biographies of those court officers, on which there is no information in other contemporary sources.

Previous Scholarship It must be stressedin that in the beginning research focused on the issues of the development of law in the GDL and dealt with the law court as an institution only in passing. Historical scholarship of the turn of the nineteenth century was dominated by the discussion about the influence of which country - Russia or Poland - affected more the formation of the land court in the GDL. The majority of historians were inclined to accentuate Polish influence on the formation of the powiat land court in the GDL. Admittedly, some Russian historians (e.g. Fiodor Leontovich ${ }^{17}$ ) considered that the basis of the law system of the GDL was impacted by Russian law, though the majority of them stressed strongly the importance of the Polish model for the formation of the Lithuanian land court system (Dovnar-Zapolskii, ${ }^{18}$ Mikhail Iasinskii, ${ }^{19}$ Maksimeiko $\left.{ }^{20}\right)$. The effect of the Polish model on the genesis of the land court of the GDL was also acknowledged by Oskar Halecki, ${ }^{21}$

${ }^{13}$ A. Boniecki, Herbarz Polski, i-xvi (Warsaw, 1899-1913).

${ }^{14}$ S. Uruski, Herbarz szlachty polskiej, i-xv, (Warsaw, 1904-1931; reprint 1994-2000).

${ }^{15}$ K. Niesiecki, Herbarz Polski, 1-10 (Warsaw, 1839-1846).

${ }^{16}$ T. Żychliński, Złota ksiega szlachty polskiej, i-xxi (Poznań, 1879-1908); Polska Encyklopedia szlachecka, 1-12 (Warsaw, 1935-1938); M. Rogucki, J. Zalewski, Rody szlachty polskiej (Warsaw, 1993); J. Ciechanowicz, Rody rycerskie Wielkiego Księstwa Litewskiego, i-v (Rzeszów, 2001).

${ }^{17}$ F.I. Leontovich, 'Oblastnye sudy v Velikom Kniazhestve Litovskom', Zhurnal Ministerstva Iustitsii, xvi, no. 9, (Nov. 1910), pp. 83-130, no. 10 (Dec. 1910), pp. 85-128; idem, 'Soslovnoi tip territorialno-administrativnogo sostava Litovskogo gosudarstva i ego prichiny', Zhurnal ministerstva Narodnogo Prosveshcheniia (June 1895), pp. 366-403), (July), pp. 1-20.

${ }^{18}$ M. Dovnar-Zapolskii, Polsko-litovskaia uniia na seimakh do 1569 goda. Istoricheskii ocherk (Moscow, 1897).

19 M.N. Iasinskii, Glavnyi Litovskii Tribunal, ego proiskhozhdenie, organizatsiia i kompetentsiia. Proiskhozhdenie Glavnogo Litovskogo Tribunala, 1 (Kiev, 1901).

${ }^{20}$ N.A. Maksimeiko, Seimy Litovsko-russkogo gosudarstva do Liublinskoi unii 1569 g. (Kharkov, 1902).

${ }^{21}$ O. Halecki, Dzieje unii Jagiellonskiej, 1 (Cracow, 1919), 2 (1920); idem, 'Sejm obozowy szlachty litewskiej pod Witebskiem 1562 r. i jego petycją o unię z Polską, Przegląd Historyczny, 18 (1914), pp. 320-352. 
Stanisław Kutrzeba, ${ }^{22}$ Juozas Gabrys, ${ }^{23}$ Šapoka, ${ }^{24}$ and Janulaitis, ${ }^{25}$ and some of them (Balzer, ${ }^{26}$ Adamus ${ }^{27}$ ) even called the late-sixteenthcentury law of the GDL a part of Polish law. The imitation of Polish law in the formation of the Lithuanian land court was also noted by some late-twentieth-century historians ( Picheta, ${ }^{28}$ Mečislovas Jučas, ${ }^{29}$ Marceli Kosman, ${ }^{30}$ Jerzy Ochmański, ${ }^{31}$ Lulewicz, ${ }^{32}$ and Błaszczyk ${ }^{33}$ ). Bardach even devised a theoretically founded concept of a voluntary takeover of the court system based on the Polish model. ${ }^{34}$ This opinion was held widely in the latter half of the twentieth century and in the works of Soviet historians in the last decades. Currently the attitudes to the court reform of the sixteenth century have not changed significantly; only the influence of the Polish model in the reform of the GDL courts is less categorically emphasised (Natalia Iakovenko, ${ }^{35}$ Mikhail Spiridonau, ${ }^{36}$ Genadii Saganovich ${ }^{37}$ ).

${ }^{22}$ S. Kutrzeba, Historia ustroju Polski w zarysie, Tom drugi: Litwa (Warsaw, 1914).

${ }^{23}$ J. Gabrys, Lietuvių-lenkų unija. Keli praeities ruožai paminëjimui 500 metų sukaktuvių Gardelio unijos (1413-1913) (Philadelphia, 1915).

${ }^{24}$ A. Šapoka, 'Bajoriškoji ,demokratija““, Lietuvos praeitis, I, 2 (VilniusKaunas, 1941), pp. 467-540; idem, Lietuva ir Lenkija po 1569 m. unijos (Kaunas, 1938).

${ }^{25}$ A. Janulaitis, Lietuvos visuomenès ir teisès istorija (Tilžè, 1920); idem, Vyriausiasis Lietuvos tribunolas XVI-XVIII amž. Jo atsiradimas, veikimas ir reikšmé Lietuvos gyvenime (Kaunas, 1927).

${ }^{26}$ O. Balzer, Historia ustroju Polski (Lvov, 1933).

${ }^{27}$ J. Adamus, 'Z zagadnień prawa litewskiego', Pamiętnik historyczno-prawny, II, 3 (Lvov, 1926), pp. 97-150.

${ }^{28}$ V.I. Picheta, Belorussiia i Litva XV-XVI v. (Moscow, 1961), idem, Istoriia Litovskogo gosudarstva do Liublinskoi unii (Vilnius, 1921).

29 M. Jučas, Lietuvos ir Lenkijos unija (XIV a. vid. - XIX a. pradžia) (Vilnius, 2000); idem, Nuo Krèvos sutarties iki Liublino unijos (Kaunas, 1970).

${ }^{30}$ M. Kosman, Historia Bialorusi (Warsaw, 1979).

31 J. Ochmański, Historia Litwy (Warsaw, 1967); J. Ochmanskis, Senoji Lietuva (Vilnius, 1996).

${ }^{32}$ H. Lulewicz, Gniewów o unię ciag dalszy. Stosunki polsko-litewskie w latach 1569-1588 (Warsaw, 2002).

${ }^{33}$ G. Błaszczyk, Litwa na przełomie średniowiecza i nowożytności (Poznań, 2002).

${ }^{34}$ Bardach, Studia z ustroju i prawa Wielkiego Księstwa Litewskiego XIV-XVII wieku (Białystok-Warsaw, 1970); idem, 'Uczone prawo w II Statucie Litewskim', Antrasis Lietuvos Statutas. Respublikinès mokslinès konferencijos, skirtos Antrojo Lietuvos Statuto 425-osioms metinèms pažymèti, medžiaga (Vilnius, 1993), pp. 15-23.

${ }^{35}$ M.N. Iakovenko, Ukrainska shliakhta z kintsia XIV do seredini XVII st. (Volyn i Tsentralna Ukraina) (Kiev, 1993); idem, Paralelnii svit. Doslidzhenniia $z$ istorii uiavlen ta idei $v$ Ukraini (Kiev, 2002).

${ }^{36}$ M.F. Spiridonau, 'Z sivoi dauniny', Pamiats. Gistoryka-dakumentalnaia khronika Liakhavitskaga raiona (Minsk, 1989), p. 35.

37 G. Saganovich, Narys gistoryi Belarusi ad starazhytnastci da kantsa XVIII stagoddzia (Minsk, 2001). 
Lithuanian legal historians investigated the appearance of the land court mainly in the framework of the general state reforms, carried out in the adoption of the Second Statute between 1564 and 1566 (Konstantinas Jablonskis, ${ }^{38}$ Konstantinas Avižonis, ${ }^{39}$ Stasys Vansevičius, ${ }^{40}$ Evgenii Machovenko ${ }^{41}$ ). The Second Lithuanian Statute has also been investigated by Vytautas Raudeliûnas, ${ }^{42}$ Stanislovas Lazutka and Aldona Vasiliauskienë. ${ }^{43}$ However, they paid greater attention to the issues of law rather than to those of law court institutions, in general conforming with the concept of Polish influence on the court system of the GDL.

Research into GDL law has served as a framework for the study of the land court as an institution. Liubavskii and Lappo were the first to examine the land court in the context of the development of Lithuanian law. Although they acknowledged the influence of the Polish court model on the structure of the GDL, they endeavoured to solve this problem avoiding categorical conclusions or statements. Liubavskii presented the most comprehensive analysis of the establishment of the land court in his work on the GDL sejm. ${ }^{44} \mathrm{He}$

${ }^{38} \mathrm{~K}$. Jablonskis, Lietuvos valstybès ir teisès istorija nuo XIV a. iki XVI a. vidurio (Vilnius, 1971).

${ }^{39}$ K. Avižonis, Bajorai valstybiniame Lietuvos gyvenime (Kaunas, 1940); idem, Lietuvos Statutai. Rnktiniai raštai, 2 (Rome, 1978), pp. 5-175.

${ }^{40}$ S. Vansevičius, Feodalinès Lietuvos valstybingumas po Liublino unijos (Vilnius, 1988); idem, LDK valstybiniai-teisiniai institutai (pagal 1529, 1566 ir 1588 m. Lietuvos Statutus (Vilnius, 1981); idem, XVI a. vidurio reformos Didžiojoje Lietuvos Kunigaikštysteje (Vilnius, 1971); Lietuvos [TSR] valstybès ir teisés istorija, ed. S. Vansevičius (Vilnius, 1997, the most up-to-date edition).

${ }^{41}$ E. Machovenko, Nelietuvišku žemiu teisine padètis Lietuvos Didžiojoje Kunigaikštystejje (XIV-XVIII a.) (Vilnius, 1999).

${ }^{42}$ V. Raudeliunas, 'Istochniki vtorogo (1566) Litovskogo Statuta', Materialy mezhrespublikanskoi nauchnoi konferentsii po istochnikovedeniiu i istoriografii narodov pribaltiiskikh respublik Soiuza SSR. Istochnikovedenie (Vilnius, 1978); idem, 'O tolkovanii iuridicheskikh terminov Litovskogo Statuta', Acta Baltico-Slavica, 7 (1970), pp. 31-44; idem, 'Seimovye postanovleniia kak istochnik Vtorogo (1566 g.) Litovskogo Statuta', Lietuvos TSR Mokslu Akademijos darbai, A serija, 3 (1976), pp. 29-42.

${ }^{43}$ S. Lazutka, Lietuvos Statutai (Kaunas, 1994); S. Lazutka, A. Vasiliauskene, 'Spiski Vtorogo Litovskogo Statuta na staropolskom iazyke', 1588 m. Trečiasis Lietuvos Statutas. Respublikiness konferencijos, skirtos Trečiojo Statuto 400 metinèms pažymèti, medžiaga. Tretii Litovskii Statut 1588 goda. Materialy respublikanskoi nauchnoi konferentsii, posviashchennoi 400-letiiu Tret'ego Statuta (Vilnius, 1989), pp. 106-125; Aldona Vladislava Paiadaite-Vasiliauskene, Kirilichni spiski Drugogo Litovskogo Statutu: palegrafiia, khronologiia, kodikologiia (Lvov, 2004).

${ }^{44}$ Liubavskii, Litovsko-russkii seim (Moscow, 1900). 
maintained that the position of the Lithuanian-Russian gentry in Bielsk accelerated the fulfilment of their old wish to have a new statute and an elected land court on the Polish pattern for the whole gentry without any exception. In actual fact, the new land court had to be a civil tribunal of the gentry estate. ${ }^{45}$ Liubavskii $^{2}$ argued that internal problems of the GDL were an important incentive for the creation of a union. The adoption of the Second Statute meant a peak in the gentry's sejm campaign - one of the first early petitions of the gentry had been an elected gentry court, legally binding for all independent land owners of a particular region. In principle, this petition had been granted already in the Bielsk Sejm of 1564. It was adopted by the Vilnius Sejm in 1565-1566 following the establishment of new boundaries of court districts and the nomination of candidates for new court offices. ${ }^{46}$

Among Lappo's works his voluminous history of the GDL of the latter half of the sixteenth century deserves special mention. In the first part of it state institutions (and law courts among them), presented chronologically and thematically, are reviewed rather statically. ${ }^{47}$ Meanwhile the second part, the most valuable with regard to the issues of the development of land courts, is an independent study, presenting a variable panorama of the formation of new territorial divisions and gentry institutions. ${ }^{48}$ The court reform is investigated in the framework of the powiat and dietine of the GDL, and the establishment of land courts and the first years of their functioning are discussed. Lappo treats the state reforms as a complex and even calls them one reform. At the start of the 1560s the need for a reform of the courts, military redistribution of the army, gentry representation in sejms, and lastly of the territorial administration was obvious in the Lithuanian-Russian state. The implementation of the reform could be achieved by introducing a new territorial division and changing the competence of the officials engaged in the courts and in the regional administration of the LithuanianRussian state. The first task was completed in the Vilnius Sejm of 1565-1566, and the second in the Bielsk Sejm of 1564, following which the high officials renounced their old rights.

${ }^{45}$ Ibid., p. 20.

${ }^{46}$ Ibid., p. 719.

47 Lappo, Velikoe Kniazhestvo Litovskoe za vremia ot zakliucheniia Liublinskoi unii do smerti Stefana Batoriia. Opyt issledovaniia politicheskogo $i$ obshchestvennogo stroia, I (St Petersburg, 1901).

${ }^{48}$ Lappo, Velikoe Kniazhestvo Litovskoe vo vtoroi polovine XVI stoletiia. 
Lappo's principal research is contained in his two-volume study of three books on the Third Statute ${ }^{49}$ In this work Lappo presents a very detailed analysis of the formation of the land court. The first part of the first volume discusses the improvement of the Lithuanian Statute starting with the first petitions to upgrade it between the 1540s and 1588. He describes the requests to 'improve' the First Statute, the course of the adoption of the Second Statute and its amendment, and the work of the commission and even its members are characterised in meticulous detail. Discussing the set-up of the land court, Lappo treats the Second Statute as central amongst all Lithuanian Statutes, because the idea of 'the gentry nation' and the estate structure of the state were developed and recorded in the chief laws. It was in the decades of the mid-sixteenth century that the GDL gentry, formerly being only land owners doing military service, became a privileged estate, 'nation-gentry', controlling the destiny of the state. In establishing gentry corporations in the powiats of the new regions, the gentry became united with the nobility by being equally subject to gentry courts and participating in common powiat dietines. The Bielsk Charter of 1564 is treated by the author as the principal issue in solving the conflict between the draft of the Second Statute and the First Statute in the sphere of legal subjection. In autonomously creating an estate-gentry organisation for the state analogous to that of Poland, the GDL gentry oriented themselves towards the state structure of Poland. The gentry looked for the verification of the applicability of its ideals in real life and sought to introduce institutions and offices similar to those in Poland. That does not mean that the GDL copied the Polish institutions in all their details, because the general laws of cultural influence were a force to be reckoned with, and the influence did not turn into submission or merger.

Lappo and Liubavskii were great connoisseurs and users of sources and historical material. Their principal works, however, were not devoted to the formation of the GDL land court system, since the topics they dealt with were more wide-ranging, and in the works of the two historians land courts were mostly referred to only in the background of other social and political changes. Neither Liubavskii nor Lappo investigated the work of the land courts of particular powiats, and neither did they distinguish the powiat land court officials as a separate gentry group. They efficiently used the Lithuanian Metrica, but they did not avail themselves of the manuscript

${ }^{49}$ Lappo, Lietuvos Statutas, vol. 1, part 1 (Kaunas, 1934); vol. 1, part 2 (Kaunas, 1936); vol. 2 (Kaunas, 1938). 
books of the powiat land courts of the GDL and stopped short at exploiting published sources (in AVAK and other series) and the inventories of land courts books of some Lithuanian powiats of the GDL, published by Ivan Sprogis.

There has not been any research on the officers of the GDL land courts as a gentry group. This topic was dealt with most comprehensively by Konstantinas Avižonis in his study about the gentry in the days of the Vasas. The GDL gentry of the period before the adoption of the Second Statute was investigated by Zbysław Wojtkowiak ${ }^{50}$ and Jüratè Kiaupienè. ${ }^{51}$ In the works of the latter half of the twentieth century a specific gentry group, known as the clientele, was studied; in these studies land court officials were also dealt with although they themselves did not feature as subjects of the research (Urszula Augustyniak, ${ }^{52}$ Antoni Mączak, ${ }^{53}$ Elżbieta Bagińska ${ }^{54}$, et al.).

Summarising the aforementioned works on the reform of law courts in the 1560s and the related administrative reform of the GDL it must be noted that the assessment of the reform was often onesided. According to a widely held opinion, striving for new land courts was a form of the emancipation of the Lithuanian gentry or a struggle for the co-equation of their rights with the apex of their estate. Bardach formulated a theory of voluntary reception in the development of the GDL with regard to the takeover of the forms

${ }^{50}$ Z. Wojtkowiak, 'Urzędnicy zarządu lokalnego na Litwie. Tytulatura zarządców powiatowych przed reformą administracyjną z lat 1565-1566', Studia Źródtoznawcze, 24 (1979), pp. 139-175.

${ }^{51}$ J. Kiaupiene, 'XVI a. ikireforminio Vilniaus pilies teismo knygos-kopijos Lietuvos Metrikoje struktūrinè ir informacinè analizè', Lietuvos Metrika. 1991/ 1996 tyrinejjimai, ed. Z. Kiaupa, A. Urbanavičius, (Vilnius, 1998), pp. 36-92; ead., 'Vilniaus vietininko Stanislavo Hamšiejaus 1559-1564 m. teismo knygos', Lietuvos miestu istorijos šaltiniai, 2 (Vilnius, 1992), pp. 61-75; ead., 'Sostav i deiatelnost suda i sudei vysazhonykh Vilniusskogo voevody v period podgotovki Vtorogo Litovskogo Statuta', Antrasis Lietuvos Statutas. Mokslinès konferencijos medžiaga (Vilnius, 1993), pp. 107-112.

${ }^{52}$ U. Augustyniak, Dwór i klientela Krzysztofa II Radziwiłla (Warsaw, 2002); ead., 'Podlaska klientela Krzysztofa II Radziwiłła', Drobna szlachta podlaska w XVI-XVIII wieku, ed. S.K. Kuczyński (Białystok, 1991), pp. 87-111.

53 A. Mączak, Klientela. Nieformalne systemy wtadzy $w$ Polsce $i$ Europie XVI-XVII w. (Warsaw, 1994).

${ }^{54}$ E. Bagińska, 'Rekrutacja klienteli radziwiłłowskiej na Podlasiu w XVIII w.', Białostoczyzna, 1 (1998), pp. 3-14; ead., 'Patronat Radziwiłłow birzańskich na Podlasiu w XVII w.', Białostoczyzna, 4 (1994), pp. 18-28. 
of Polish state organisation. Following the appearance of the works by Lappo and Liubavskii, other historians merely repeated the interpretation of their predecessors, occasionally modifying it slightly. The other aspect of the reform - the endeavour to modernise the GDL on the eve of the Union of Lublin - was not accentuated. The statement that the initiators of the system of new courts were the lesser and middle gentry had remained an almost unquestioned historiographical axiom. At the same time raising this issue does not exclude a simultaneous gentry emancipation and the adaptation of the nobility to a formal possibility of democracy; nevertheless the probability of these two parallel processes practically has not been examined. In the investigation of the administrative and law court reforms the two processes were often presented statically, chronologically lumping together the Bielsk Charter and the final adoption of the Second Statute a year and a half later.

Historical scholarship shows that attention was focused on the processes taking place in the gentry estate, while the reforms of administration and law courts were treated only as a part of those processes. The formation of the land courts was not examined.

The Process of the Formation of Land Courts This process should be taken as a continuous series of proceedings with a view of modernising the structure of the GDL courts and establishing an independent court of the gentry estate. The initial stage was a reform of the then legal rules in force - the amendment of the Lithuanian Statute, and that was followed by the actual implementation of the reform of the court system. Afterwards an appeal institution - the Supreme Tribunal of Lithuania - was set up, and the contemporary system of law courts was modified.

The First Lithuanian Statute of 1529 envisaged the establishment of the law court of two 'appointed' judges. Nevertheless, even in the 1540s there functioned the courts of vicegerents rather than of 'appointed' judges in the regions of the state. The gentry were not satisfied with that situation, and in the GDL Sejm of Brest-Litovsk in 1544 the estates asked the ruler to revise the Statute, to alter some of its articles and to publish its modified version. The powiat gentry also requested a common court of law. Sigismund the Old rejected the petition, but he agreed that the Statute needed revision and proposed that the gentry should set up a commission of ten persons. ${ }^{55}$

${ }^{55}$ Lappo, Velikoe Kniazhestvo Litovskoe vo vtoroi polovine XVI stoletiia, pp. 19-20. 
The petition was repeated at the Vilnius Sejm of 1547. Sigismund Augustus also refused to establish the sejms common to the entire gentry. The petition was repeated again at the end of the Vilnius Sejm of 1551. As the commission for the revision of the Statute had not yet been set up, the ruler himself formed it of five Catholic and five Orthodox members after a consultation with the Council of Lords.

The Podlasie court system (in the powiats of Bielsk, Melnik and Drohichin) set a good example for the Lithuanian gentry. There the gentry obtained the right of self-rule (jus Polonicum), which seriously limited the powers of legal castle starostas and established autonomous gentry courts. ${ }^{56}$ The powiat of Bielsk was the first to receive this right in $1501 ;{ }^{57}$ a similar charter was obtained by the Drohichin powiat in $1511^{58}$ and $1516,{ }^{59}$ and lastly by Melnik and Drohichin together in $1547 .{ }^{60}$ Dealing with the gentry of Podlasie, the gentry of the rest of the GDL could not but envy their judicial freedom independent of the nobility. Their first requests of elected courts indicated Podlasie as an example. ${ }^{61}$ The gentry of the GDL were fascinated by the independence from the nobility and by the idea of the judicial equality of the entire gentry 'nation' in a broad sense. That could be realised only by establishing elected law courts, and depriving the nobility the chance to manipulate the decisions of the courts.

Thus, the central demand of the gentry was the restriction of the judicial licence and privileges of the nobility. Minor concessions, granted by Sigismund Augustus in 1551, led to a gradual weakening the nobility's powers. In 1551 the main achievement of the gentry was the ruler's decree on establishing courts of 'appointed' judges, provided in the First Statute. ${ }^{62}$ In real life, however, even 20 years

${ }^{56}$ In the same book Lappo devoted a chapter for the analysis of the Podlasie courts and their attraction for the rest of the GDL. Ibid., pp. 146-167.

${ }^{57}$ See Zbiór praw litewskich od roku 1389 do roku 1529. Tudzież rozprawy o tych że prawach od roku 1544 do roku 1563, ed. T. Dzialyński (Poznań, 1841), pp. 82-91; Akty Zapadnoi Rossii, 1, no. 189 (1846); Liubavskii, Ocherk istorii, pp. 365-369.

58 Akty Zapadnoi Rossii, 2, no. 64 (1848); RIB, 20 (Sankt-Peterburg, 1903), pp. 665-666); Zbiór praw litewskich, pp. 117-118.

59 See Zbiór praw litewskich, pp. 118-121: Liubavskii, Ocherk istorii, pp. 373-376.

${ }^{60}$ M. Liubavskii, Oblastnoe delenie $i$ mestnoe upravlenie Velikogo Kniazhestva Litovskogo ko vremeni izdaniia Pervogo Litovskogo Statuta (Moscow, 1894), p. 20.

${ }^{61}$ RIB, 30 (1914), Liubavskii, Litovsko-russkii seim, p. 579.

62 Ibid., p. 579. 
after the adoption of the Statute, the noblemen or their vicegerents continued to administer justice in many courts. ${ }^{63}$ As the introduction of the 'appointed' judges was slow in coming, the initiative then belonged to the gentry, requiring from the ruler not symbolic selfrule ('appointed' judges) but formal self-government - courts common to all gentry estates, thus depriving the nobility of the privilege to be subject directly to the monarch's court. The course of events in the future showed that it was a long and difficult process, since the nobility were not inclined to revoke their privileges easily. Meanwhile the sovereign did not give the gentry much hope and forwarded the solution of the problem to the commission for the amendment of the Statute. Nevertheless, in the middle of the 1550s the courts were presided by two 'appointed' judges' instead of vicegerents in a number of powiats. ${ }^{64}$ In the sejms of 1554 and 1559 the gentry again petitioned the sovereign for reform, but Sigismund Augustus, waiting for the Statute amendment commission to end its work, proposed only minor changes. ${ }^{65}$ Finally in the military camp at Vitebsk in $1562^{66}$ the gentry formed a federation and required common courts and a union with Poland. ${ }^{67}$ After arriving to Poland for the negotiations on the conditions of a union, the Lithuanian noblemen, finding themselves in an awkward situation, also began talking about the necessity of the reform and the union. The adoption of the Statute in the Vilnius Sejm of 1563 was postponed until the sejm, which would be convened 'twenty weeks after the dissolution of the army in 1563 '.68

${ }^{63}$ For example, that is attested by the first three books of the 'land' court of Grodno (1539-1542); see AVAK, 17 (Vilnius, 1890), pp. 1-396.

${ }^{64} \mathrm{Cf}$. the books (and their fragments) of the land court of Grodno, AVAK, 17, 21 (1890, 1894); the first book of the land court of Slonim, AVAK, 22 (Vilnius, 1895), pp. 1-146, or Vilnius castle court books, preserved in the Lithuanian Metrica; see also J. Kiaupiene, 'Knigi Vilniusskogo zamkovogo suda XVI v. v sostave Litovskoi Metriki', Lietuvos Metrika. 1988 m. tyrinejjimai (Vilnius, 1992), pp. 71-84. These books are discussed in detail in recent research, see ead., 'XVI a. ikireforminio Vilniaus pilies teismo knygos', pp. 36-92.

65 Liubavskii, Litovsko-russkii seim, p. 598; Lappo, Velikoe Kniazhestvo Litovskoe vo vtoroi polovine XVI veka, pp. 17-18.

${ }^{66}$ O. Halecki, 'Sejm obozowy szlachty litewskiej pod Witebskiem 1562 r. i jego petycja o unię z Polską', Przeglad Historyczny, 18 (1914), pp. 320-352. Lulewicz, however, doubts the consciousness of the Lithuanian gentry and in the federation sees only the rivalry between the Radvilas and the Chodkevičiuses; see his Gniewów o unie ciag dalszy, p. 19.

${ }^{67}$ Liubavskii, Litovsko-russkii seim, pp. 635-636.

${ }^{68}$ RIB, 30, 1914; Lappo, Velikoe Kniazhestvo Litovskoe, p. 18. 
The sejm of the GDL gathered in Bielsk on 1 June 1564. The main document it adopted was the so-called Bielsk Charter of 1 July 1564, abolishing the judicial privileges of the nobility. ${ }^{69}$ This privilege was the first stage in the establishment of the land court. It envisaged some essential changes in the court system: the abolition of the judicial exceptions for the nobility and the creation of one territorial land court for the entire gentry estate as well as the election of new court officials; it also indicated the date for the start of the functioning of the new courts. A great novelty was the electiveness of court officers and the set-up of one law court for the entire gentry estate in a broad sense.

The new Lithuanian Statute and the order it imposed had to come into effect on St Martin's day, 11 November 1564. A provision was made for old cases, which had to be examined by new judges according to the old Statute and customary law.

Although the Bielsk Charter was a document marking the beginning of the reform, the establishment of the land courts did not start in the powiats in 1564. Neither did the new Lithuanian Statute take effect. In practice, after the Sejm of Bielsk the set-up of land courts depended on the initiative of particular powiats. As a Muscovite army appeared at Vilnius, the matters of defence were more important for the ruler than the establishment of courts. The old powiat regiments, more precisely those of small powiats, were enlarged according to new judicial powiats. In the sixteenth century drawing the boundaries of the powiats and their description was a slow and complex process, involving meticulous preparatory work. New configurations of the powiats had to be established according to rivers, lakes, forests, lands of estates, etc. Land-surveyors had to define important topographical points, to mark new boundaries, to fix landmarks, etc. The prevalence of small old powiats ${ }^{70}$ in the 1565 muster rolls of the GDL leads to the conclusion that at that time new powiats were not yet formed or that the military territorial structure of the GDL was not yet matched with the territories of new land courts.

${ }^{69}$ See Liubavskii, Litovsko-russkii seim, pp. 678-679. The text of the privilege is found as Prilozhenie no. 48, pp. 133-140.

${ }^{70} R I B, 1915$, vol. 33, coll. 237-430 (1565): col. 271 - the regiment of Krèva, 274 - Medininkai, 276 - Rudamina, 281 - Nevėžis, 286 - Geranainys, 289 Giedraičiai, 292 - Nemenčinè and Maišiagala, 294 - Kernave, 295 - Anykščiai, 297 Punia, 298 - Kurkliai, 304 - Kobrin, 325 - Vasiliškès, 330 - Ostrynia, 332 - Kaniava and Rodūnia, 334 - Eišiškès, 336 - Semeliškès and Lieponiai, 337 - Daugai and Perloja, 339 - Žiežmariai, 340 - Aukštadvaris, 341 - Stakliškès, 342 - Alytus, and other regiments. 
The formation of land courts was a complicated process with its months of haste and years of stagnation. Proceeding slowly before the declaration of the Bielsk Charter in 1564, the judicial and administrative reforms accelerated before the adoption of the Second Statute. In 1566 a new stage of the formation of land courts began their functioning was elaborated and supplemented. Despite the politically unstable period between 1572 and 1576 this process continued until the enactment of the Third Lithuanian Statute in 1588. Thus, three periods can be distinguished in the reform of the land courts in the GDL: (a) the preparatory stage - between 1551 and 1564 (the Bielsk Charter); (b) the actual formation of the land courts in powiats between July 1564 and January 1566; and (c) the elaboration of the functioning of the land courts - until 1588.

This reform took several decades (starting with the establishment of the commission for the preparation of the Second Statute) and coincided with many other events in the history of the GDL, some of which (e.g., wars) did not contribute to the implementation of the reform. Looking at the events from a historical perspective one can see that the second half of the sixteenth century, and in particular its seventh to ninth decades, was a period of various changes in the life of the GDL. The reform of the courts doubtless was one of the most significant innovations in the internal life of the state. The establishment of the land court marked radical changes in the social structure of Lithuanian society, introduced a judicial equality (it was formal, but nevertheless new) within the ruling estate and actually ended the formation of a united gentry 'nation'. Internationally this reform was a factor proving that Lithuania was an equal partner in the union with Poland in terms of its internal structure.

The need for an elected land court covering the whole gentry estate had been felt since the mid-1540s when requests to 'amend' the First Lithuanian Statute were brought before the Sejm. The First Statute had also envisaged the courts of 'appointed' judges, nevertheless even in the middle of the sixteenth century they were not established in many powiats.

The beginning of the land court reform was speeded up by some external factors - the failure in the Livonian War and preparations for the union with Poland. The reform was not a onetime action of the sovereign's will. The 1564 Bielsk Charter was only an introduction to reform proper. It was followed by a revision of the Second Statute, which lasted nearly two years until the beginning of 1566. The reform of the territorial division of the GDL was also carried out for legal and military purposes. 
The modification of the Second Statute started soon after the Statute was adopted. The greatest innovation in the system of courts was the establishment of the Supreme Lithuanian Tribunal, a higher appeal court, in 1581. The commission for the preparation of the Third Statute was first appointed by an instruction of the ruler; and subsequently it was composed of the representatives elected by the powiats. The new statute was drawn up early in 1584 .

The adoption of the Third Statute in 1588 concluded the formation of the powiat land courts in the GDL. The land courts acquired their final shape, which existed until their alteration in 1764. Meanwhile on the territory of the former GDL (except in Užnemune, the south-western part seized by Prussia) the Third Statute remained in force until 1840 .

The Work of the Land Court (1565-1588) The initiators of the administrative and legal reforms - the sejm and the ruler of the GDL did not issue any regulations on the order determining the sequence of steps in forming a land court in the powiat. All that had to be done by the local gentry community of the powiat. In this process many things were common for all powiats, but some features could be specific in a particular district.

The order of the election of new officials, places of the sessions of the courts and of keeping land court books had to be defined, ${ }^{71}$ and theretofore it was necessary to endorse the Second Statute regulating the work of the land courts. In Ugrov, Podlasie, a gathering had to take place for the solution of these problems, however a war prevented it.

Many technicalities had to be solved independently in each powiat. Even after fixing the boundaries of legal districts and electing their officials, it was necessary to set up (zasadit', in the language of the original) the land court in each powiat. The officers (from among four proposed) had to be appointed by the sovereign's writ, and they had to be sworn in in the presence of the powiat gentry. The procedure of the establishment of the land court was described in great detail in the beginning of the Slonim land court book of $1565-1566 .^{72}$

In many powiats of the GDL land courts were established in 1565 , although the Second Statute came into force finally merely at

${ }^{71}$ Liubavskii, Litovsko-russkii seim, p. 679.

${ }^{72}$ AVAK, 22 (1895), pp. 147-148. 
the beginning of 1566. The functioning of the land courts could be interrupted only by important matters of the state (sejms, wars), epidemics, death or promotion of a court officer during the election of a new candidate. An electoral dietine of the powiat was summoned and the whole procedure of the appointment of a new officer could take several weeks or months.

Sometimes land court sessions were moved to some other date due to protracted work of the sejm ${ }^{73}$ or military campaigns (Grodno, 1579-1581 ${ }^{74}$ ). Such interruptions, however, were rare, and the courts functioned according to the procedure established by the Second Statute, which then stood good.

Exact dates for the setting up of land courts in particular powiats are impossible to determine in many cases, since the foundation charters have not always been preserved, and manuscript court books proper of only six powiats of the GDL are extant. The first land court books have usually been lost, and only allusions in some other documents give some idea of the early functioning of the courts. In some regions of the GDL the formation of land courts was delayed for several years due to wars. The last land court in the GDL could be established in Lepel (Polotsk palatinate) in the summer of $1570 .^{75}$

In addition to the few surviving land courts books of the GDL powiats, there are many extracts from lost books, and that attests to the more or less normal functioning of the courts.

It is not hard to guess that after 1564 the new powiat land courts functioned as castle courts and possibly even replaced them in some regions of the GDL (Kaunas, Slonim, Upytè). That is

${ }^{73}$ Cf. the Slonim Land Court Book no. 2 (1567-1570), Natsyanalny gistarychny arkhiu Belarusi y Minsku, f. 1785, op. 1, d. 2, page 51 of which contains a copy of the decision of the Sejm of Grodno to the effect that in accordance with this letter the gentry convened their extraordinary land court session on St Bartholomew (24 September). This session lasted until 11 September (62 inscriptions, fos. 51-115v); then followed an ordinary autumn session (September 23 - October 1568) of the land court.

${ }^{74}$ Fo. $362 \mathrm{v}$ of the book no. 7 of Grodno land court (BNIA, f. 1755, ap. 1, d. 7) contains an inscription (its date 7 October 1578 (sic) is doubtful), in which the land court scribe Andrei Kotovich informs that the land court of Grodno could not sit because of the war against Ivan IV between 1579 and 1581 .

${ }^{75}$ All three appointments of officers took place the same day, cf. Lithuanian Metrica-267/53, fos. 311r-v, 28 July 1570, charter for L. Harabuda of Polotsk (land) district judge; ibid., fo. $311 \mathrm{v}$, charter for I. Nevelskii of Polotsk deputy district judge; ibid., fo. 312, for V. Korsak of Polotsk court scribe. 
attested by 'continuous' land court books and by the manner of their keeping similar to that of castle court books.

The work of the land courts in the form of sessions, foreseen in the Second Statute, became established around 1570. Prior to that date occasionally there had been 'continuous' land court books. In some regions (Ašmena, possibly Trakai, and after 1589 in Ukmergë) the powiat land court sessions were conducted in several places. Unlike in Poland, at that time all powiat land courts worked simultaneously three times a year (in January, June and October). Court terms were different only in the powiat of Novogrudek, they were established by a decree of the Sejm in $1601 .^{76}$

The new land courts also performed notarial functions. Extracts from land court books were treated as official documents, therefore there were cases when such extracts were given to the gentry and presented documents were recorded in the books even when the court was not working.

Between 1564 and 1588 the work of land courts was interrupted by interregnums, wars and epidemics. During 17 years in that period there were 18 sejms; there is evidence that in some places land courts worked during the sessions of the sejm, although according to the Second Statute they had to suspend their activity several weeks before and during the sejm.

After the establishment of the Supreme Tribunal of Lithuania in 1581 the court sessions did not take place in those powiats in which the Supreme Tribunal was in session (Trakai, Vilnius, Novogrudek, Minsk) until 1588. This is attested by the schedule of the Supreme Tribunal and by extracts from land court books of those powiats (the books themselves have not survived).

\section{The Officers of the Powiat Land Court (1566-1588). The First} Generation of Gentry 'Lawyers' The Bielsk Charter (1564) is a hallmark in the history of powiat land court officers. Four candidates for each post had to be elected in the electoral dietine of the powiat. From twelve candidates the grand duke appointed three persons to the positions of land court officials. A court official could be only

76 'All estates agreeing and permitting ... once and for all ...' Volumina Legum, 2, p. 403, § 125. There three sessions are indicated, but their beginning is different: (1) St Mark's Day (25 April), (2) All Saints' Day (1 November) and (3) Candlemas (2 February). This order had to be established on All Saints' Day in 1601. In his reminiscences T. Ievlashevskii mentioned that in 1603 the land court worked according to the new order in Novogrudek. 
a gentry representative of Christian faith, known for his good morals, be acquainted with law and possess immovable property (an estate, land) in that particular powiat. The scribe had to be able to write in 'Cyrillic characters'. ${ }^{77}$ The posts of this court could not be occupied by clergymen or by persons having positions in the land courts of other powiats. The appointments were for life or until promotion.

The hierarchical place of land court officers was defined by the decrees of the GDL Sejm and the Lithuanian Statute. It is noteworthy that in the course of time their status rose in the midst of the regional elite. According to the 1567 decree of the Grodno sejm, the land court judge, deputy judge and scribe occupied the sixth to eighth places after the marshal, elder, chamberlain, standard-bearer and voiski; while the Third Statute (1588) indicated the fourth and fifth places for the judge and deputy judge after the marshal, chamberlain and standard-bearer, and only the land court scribe was placed at the end of the list after the voiski, butler and deputy butler. ${ }^{78}$

The personal composition of the land court officers of the GDL remains one of the least investigated (and most interesting) issues of the new legal institution. In this work an attempt is made to recreate the general personal composition of the officials of the powiat land courts between 1566-1588. It is especially difficult to follow the succession of the land court officers in those powiats, which have not preserved their land court books (e.g. in Vilnius). Even the Lithuanian Metrica does not present a full panorama of the turnover of land court officials in the last decades of the sixteenth century. That is probably due to the fact that not all appointments were recorded and that a part of the Lithuanian Metrica has not been preserved. In cases when direct accounts of the appointments were missing in the Metrica or in the powiat land court books, the search for information about court officials was continued in the books of other powiat (castle, chamberlain) courts.

In the creation of new powiat courts previous experience of keeping records was taken into consideration, too. The new offices engaged former officials of the old courts. Therefore it is worth analyzing the activities of the individuals before they became court officials. The appointment dates of the first officers of the new

77 Statut Vialikaga kniastva Litauskaga 1566 goda, ed. T.I. Dovnar, et al. (Minsk, 2003), 4, 1, p. 97.

${ }^{78}$ III Lietuvos Statutas, 3, 6; see also Statut Vialikaga kniastva Litauskaga 1588 goda, p. 116. 
courts could be determined on the basis of the contemporary books of the Lithuanian Metrica, however their data are not exhaustive. There is more information only about the appointments of the officials in the new powiats and palatinates in the first half of 1566. ${ }^{79}$ Thus it seems that the ruler did not issue new privileges for the powiats, which had pre-reform courts of appointed judges. There the appointed judges simply became the officers of new land courts, though this was not always the rule. ${ }^{80}$ The pre-reform Vilnius court castle could be treated as a sort of training ground for future land lawyers, since a number of land court officials of other regions began their careers in the capital. Thus, Adomas Rusteikavičius, a member of the Vilnius castle court between 1559 and $1564,{ }^{81}$ was a scribe of the land court of Žemaitija. ${ }^{82}$ The deputy judge (1581$1592^{83}$ ) of the Lida land court Martin Songin had worked as a judge of the Vilnius castle court between 1570 and $1576 .{ }^{84}$ Former castle court officials were appointed land courts officers later as well. E.g., Pavel Porosukov-Uglovskii, a former castle judge of Orsha, became an assistant judge of the land court in the same city in $1585 .^{85}$ Mikalojus Burba, in 1590 mentioned as a castle court scribe of Žemaitija, ${ }^{86}$ became a land court scribe there in $1591 .{ }^{87}$ Grigas Beinartas, a scribe of the castle court of Žemaitija between 1572 and $1579,{ }^{88}$ became a deputy judge of the land court of Kaunas in $1580 .{ }^{89}$ After some time the scribe of the court castle of Žemaitija

${ }^{79}$ On the appointments of court and other officials in the new palatinates in the spring of 1655, see the books of the LM-48 (four privileges), LM-267/53 (two privileges), LM-44, 47, 50 and 51.

${ }^{80}$ E.g., the appointed judge Mikalojus Šimkaitis Toločka, a judge of the 'land' court of Grodno (BNIA, f. 1755, op. 1, d. 2) was referred to as a castle court judge in the Grodno post-reform land court book no. 6 (1571)

${ }^{81}$ Kiaupienè, 'Vilniaus vietininko Stanislavo Hamšèjaus $1559-1564$ m. teismo knygos', p. 68.

${ }^{82}$ He died early in 1591; on the appointment of his successor on 22 May 1591, see LM-85, fo. 156.

${ }^{83}$ Urzędnicy Wielkiego Księstwa Litewskiego. Spisy, Tom I. Województwo Wileńskie XIV-XVIII wiek (Warsaw, 2004), p. 360.

${ }^{84}$ Ibid., p. 167.

${ }^{85}$ Appointment of 15 Dec. 1585. LM-73, fo. 116, LM-74, fos. 50r-v.

${ }^{86}$ LMAB, RS, f. 256 , b. 995 , fo. 31.

${ }^{87} \mathrm{He}$ died in 1604, the election of his successor took place on 16 May 1604, LM-85, fos. 276r-v, LM-86, fo. 417v.

${ }^{88}$ LMAB, RS, f. 256 , b. 995 , fo. 31.

${ }^{89}$ Appointed a land court deputy judge on 4 Jan. 1580 (after M. Posudkovskii's death), LM-66, fo. 7v. 
Florijonas Beinartas (1585-1589 $)^{90}$ became a deputy judge of the land court of Upyte (1592-1608). ${ }^{91}$ Fiodor Shaula was a deputy starosta of Minsk, ${ }^{92}$ and conjointly from 1580 he held the post of an assistant judge of the Polotsk land court (until 1580 he was a land court scribe). ${ }^{93}$ The scribe Mikalojus Kulvenskis, having worked in the Kaunas castle court in 1582, became a land court deputy judge in 1591 , and his deputy in the castle court (podpisok) S. Lavdboras became the scribe of the Kaunas land court between 1599 and 1601. Opposite cases were possible, too: Fiodor Tushevitskii (the son of the first Slonim land court scribe Bogusz Tushevitskii between 1565 and $1578^{94}$ ) having worked as the Slonim castle court judge since $1580 \mathrm{~s} .{ }^{95}$ Mikalojus Gruzdys (the son of the scribe of the land court of Žemaitija Stanislavas Gruzdys between 1566 and $1576^{96}$ ) became the deputy starosta of Upyte, ${ }^{97}$ and his other son Povilas Gruzdys was mentioned as the judge of the castle court of Žemaitija between 1570 and $1575 .{ }^{98}$

The names of land court officials of the GDL can be found in many written sources of that time, for example, among the names of tax collectors, or the signatures to the act of the Union of Lublin. Their names can also be found in various economic documents, which abound in the Lithuanian Metrica and other written records. It must be noted that such estimates have been made in relation to the territories that passed to Poland after 1569, and we could only have recourse to the works of Polish and Ukrainian historians. ${ }^{99}$

The two decades that followed the adoption of the Second Statute were the initial stage of the work of land court officials of the GDL. Conditionally this gentry group could be called powiat

${ }^{90}$ LMAB, RS, f. 256 , b. 995 , fo. 31.

${ }^{91}$ Appointment of 14 March 1592. LM-77, fos. 297-298, LM-78, fos. 123v-124.

${ }^{92} \mathrm{He}$ is referred to as an assistant starosta of Minsk during the whole second half-year of 1852 in the Minsk castle book of 1582, see AVAK, 36 (1912), between 20 June and 4 Jan. (pp. 143...341), and 23 Nov. 1582, see LMAB, RS, f. 16, b. 75, fo. 119.

${ }^{93}$ Appointment of 17 Jan. 1580. LM-66, fos. 44r-v, LM-212, fo. 15.

94 Appointed on 1 June 1565, AVAK, 22 (1895), p. 148.

${ }^{95} \mathrm{He}$ is often mentioned in this position in the 1580 s, see LMAB, RS, f. 16 , b. 49,75 , etc.

${ }^{96} \mathrm{He}$ died at the end of 1576, and his successor was appointed on 6 Dec. 1576; LM-56, fo. 87v and 12 Dec. 1576; LM-58, fo. 135.

${ }^{97}$ Mentioned in that post in 1586; AVAK, 26 (1899), pp. 192-496.

${ }^{98}$ LMAB, RS, f. 256, b. 995 , fo. 96.

${ }^{99}$ Urzędnicy podlascy XIV-XVIII wieku. Spisy, comp. E. Dubas-Urwanowicz, et al. (Kórnik, 1994), pp. 43-44, 50, 55, 75-76, 82, 86, 109-110, 116, 119. Iakovenko, Ukrainska shliakhta, pp. 188-190. 
'lawyers'. This was the period of the formation of the dynasty of land court 'lawyers', which worked in the land courts of one or several neighbouring powiats. With respect to their wealth they could be attributed to the middle gentry.

The majority of the land court officials of the GDL were close or distant relatives. However, the very corporation of 'lawyers' was not closed. Kinship relationships also pervaded the highest powiat posts and senators, and the same network of relationships was common in the circles of the lesser gentry. Many late-sixteenth-century families of powiat land court officers emerged in the seventeenth and eighteenth centuries and became senators of the GDL (the Mlečkas, Belozarases, Kuncevičiuses, Volodkievičiuses, Giedraitises, Masalskises, et al.).

A comparison of the list of land courts officials of this period with that of the household and clientele of the palatine of Vilnius Mikalojus Radvila the Red suggests that a great number of those court officers obtained their posts with the help of their influential patron. ${ }^{100}$ Consequently, a number of these formally independent land court officials were stooges of the nobility.

Conclusions The formation of the powiat land court of the GDL started in the late 1540s as a movement for the amendment of the First Lithuanian Statute and continued even after the adoption of the Second Statute in 1566, resulting in its revision. This process was conditioned by the emancipation campaign of the Lithuanian gentry. On the other hand, the efforts of the GDL elite to modernise the state cannot be ignored. In that period Polish voices requiring a full incorporation of the GDL (even effacing the name of Lithuania) were becoming louder. An important external factor - the Livonian War - manifested that Lithuania alone could not withstand the Russian onslaught. The political elite of the GDL had to make concessions in order to draw support from the gentry in foreign affairs.

The powiat land courts of the GDL were established formally as a result of the administrative and legal reform of 1564-1566. In many places, however, the functioning of new judicial institutions was confronted with various internal (lack of premises) and external (wars) difficulties. Actually the work of the new courts began between 1565 and 1570; and their regular activities according to the requirements of the Second Statute began only after the Livonian War in the early 1580 s.

${ }^{100}$ R. Ragauskienè, Lietuvos Didžiosios Kunigaikštystès kancleris Mikalojus Radvila Rudasis (apie 1515-1584 m.) (Vilnius, 2002), pp. 305-376. 
The sessions of the land courts had been planned in several places in the powiat (as in Poland), but at the end of the sixteenth century this type of organisation was not yet standard practice. Historical scholarship often states that the GDL gentry copied the structure and procedural matters of Polish land courts. However the Polish order - sessions of the land court in different places and at different times - was not yet widespread and such practice was rather an exception than a rule in that period. In the majority of the GDL powiats the sessions were held in the same place three times a year.

The powiat land courts were usually guided in their work by the Second Statute. Sometimes land court sessions were moved to some other date due to protracted work of the sejm, wars, or epidemics. Such interruptions, however, were rare.

Sources show that there were about 260 land court officials in the period between 1566 and 1600 . Conditionally members of this group can be called powiat 'lawyers', since they were the first originators of the new juridical culture in the latter half of the sixteenth century. With respect to their wealth, they could be attributed to the middling gentry, who controlled from several to a dozen services and could equip from several to some dozen footmen or horsemen for the army. Among them there were some much richer individuals, but in the 1570 s and 1580 s they were soon promoted from land courts to higher posts of state administration. Although according to the Second Statute court officers had to be elected, the very independence of land courts was only formal. And that neither confirms nor rejects the supposition that the nobility could preserve their influence upon land courts in various indirect ways.

An attempt to collate the list of the land court officials of the first generation (1566-1588) with that of the clients of Radvila the Red, a GDL senator and palatine of Vilnius, only raises serious doubts as to whether the middling and petty gentry were the winners in the struggle for their rights. The two lists coincide to a great extent, and that leads to the idea that it was not a mere coincidence, but conscious endeavours of the GDL elite to ensure their influence in the otherwise independent courts. On the other hand, land courts were a sort of ladder for the gentry on their way to the ranks of nobility.

Our study established the succession of land court officials, their kinship and the beginning of the formation of these officials as a group (excluding the lower court personnel). ${ }^{101}$ Marriage bonds were a way

${ }^{101}$ D. Vilimas, Lietuvos Didžiosios Kunigaikštystès žemès teismo sistemos formavimasis (1564-1588) (Vilnius, 2006). 
of establishing closer ties within the social group and with the representatives of the elite of the GDL. In future (in the seventeenth century) that helped some families of land court officials to rise to the rank of GDL senators. This was not a formal group, and entrants from the lesser gentry could join it and those promoted to higher posts could leave it. The work in the land courts secured both income and social prestige in the powiat. Some officials were promoted to the posts of chamberlains, marshals and even castellans. However, such cases were rare, and representatives of many families could expect to rise in status only in the following generations. One's career was also conditioned largely by the position and protection of the patron noble.

Certain relationship ties between the land court officials and the higher administrative circles of the GDL can be detected. In this period there were no land court officers among the Radvilas, Chodkevičiuses, Glebavičiuses or Kiškas, but they could be found among the Sapiegas, Druckis-Sokolinskises, Lukomskises or Giedraitises. That confirms the supposition that in the initial period of the land courts nevertheless there existed a certain psychological barrier separating land court officials from the elite of state administration. Understandably, the list of the families of low and high ranks underwent changes over time.

The system of the land court acquired its final shape after the introduction of the Third Lithuanian Statute in 1589. Although according to the Second Statute land court officials had to be elected, the very independence of the courts was merely formal. And that neither confirms nor denies the fact that the nobility could control the courts in other indirect ways.

The appearance of new honorary positions in the powiats at the end of the sixteenth century (which is not an object of this research) supports the assertion that these positions were not only an additional indicator of the gentry's superiority but also a kind of ladder to the posts in the land court. The objective of the land court reform was achieving equality before the law for the whole ruling gentry 'nation'. The land court, created on the Polish pattern, was formally independent of the ruler and of powiat administration. The ruling families of the GDL nobility, however, lost neither their wealth nor high posts. Probably the opposite was true - in the formally independent courts there were many stooges and clients of the noblemen, and that shows that they retained their power. The rivalry for the influence in the land courts acquired a new, more refined quality. In this situation the nobility could rely on their wealth, social status, 
political and diplomatic experience. Officially democratised courts could be controlled by a nobleman's own appointees. Thus, there appeared a chance to examine the relationship between the formal (desired) and the real situation in the powiat land courts and to look for new criteria for assessing the development of GDL society in the late sixteenth century.

In conclusion, it can be stated that, on the one hand, a court of an entirely new type was created and started functioning in the GDL between 1564 and 1588; on the other hand, it is obvious that there still remained a strong connection with the pre-reform period in the selection of officials for the powiat land courts.

Translation: Alfonsas Laučka

\section{Author Details}

Darius Vilimas is a junior researcher in the Department of the History of the GDL of the Lithuanian Institute of History. His sphere of interest is the formation of the system of land courts in the late sixteenth century and the regional service gentry in the GDL.

Address: Department of the History of the GDL, Lithuanian Institute of History, Kražiu 5, Vilnius LT-01108, Lithuania

Email: vilimas@istorija.lt; dariusvilimas@hotmail.com

\section{LIETUVOS DIDŽIOSIOS KUNIGAIKŠTYSTĖS ŽEMĖS TEISMO SISTEMOS FORMAVIMASIS (1564-1588)}

Santrauka

\section{DARIUS VILIMAS}

Straipsnyje nagrinėjamas Lietuvos Didžiosios Kunigaikštystès žemės teismo sistemos susiformavimas XVI a. antrojoje pusëje (1564-1588), prièmus Antraji Lietuvos Statutą. Tyrimo objektu pasirinktas naujo tipo renkamas pavieto žemės teismas, simbolizavęs bajoriškają savivaldą. Taip pat tiriama besiformuojanti naujojo teismo pareigūnų (teisėjas, pateisèjis, raštininkas) grupè, sudariusi tarnybinį regionų bajorijos tarpsluoksni, savotiškus ,juristus“.

Trumpai apžvelgus bajoriškojo teismo atsiradimo ir jo darbo pradiniame etape peripetijas, peržvelgiama pareigūnų sudètis. Palyginus juos su viena iš magnatų klientų grupe, konstatuojama, kad tarp formaliai nepriklausomo žemès teismo pareigūnų yra ir didelè dalis Vilniaus vaivados M. Radvilos Rudojo klientų. Todèl galima spèti, kad magnatai ieškojo būdų (ir juos rado) išlaikyti savo itaką ir naujojo tipo teismuose, nors pati teismo sistemos reforma ir žemès teismo įūrimas deklaravo visiškai priešingus tikslus - panaikinti iki $1564 \mathrm{~m}$. buvusią didikų hegemoniją teismuose ir įkurti vieną bendrą teismą visam bajorų luomui plačiaja prasme. 